\title{
Regulation of the $\beta$-Adrenergic Receptor Signaling Pathway in Sustained Ligand-Activated Preconditioning $\mathbf{s}$
}

\author{
DL. E. See Hoe, ${ }^{1}$ DS. R. Foster, ${ }^{2}$ L. Wendt, H. H. Patel, J. P. Headrick, and J. N. Peart \\ Menzies Health Institute Queensland, Griffith University, Southport, Queensland (L.E.S.H., L.W., J.P.H., J.N.P.); School of \\ Biomedical Sciences, University of Queensland, Brisbane, Australia (S.R.F.); and VA San Diego Healthcare System and \\ University of California San Diego, San Diego, California (H.H.P.)
}

Received June 28, 2018; accepted January 10, 2019

\begin{abstract}
Sustained ligand-activated preconditioning (SLP), induced with chronic opioid receptor (OR) agonism, enhances tolerance to ischemia/reperfusion injury in young and aged hearts. Underlying mechanisms remain ill-defined, although early data implicate phosphoinositide 3-kinase ( $\mathrm{PI} 3 \mathrm{~K}) /$ protein kinase $\mathrm{B}$ (Akt) during the induction phase, and $\beta_{2}$-adrenoceptor $\left(\beta_{2}-A R\right), G_{s}$ alpha subunit $\left(\mathrm{G} \alpha_{\mathrm{s}}\right)$, and protein kinase A (PKA) involvement in subsequent cardioprotection. Here, we tested for induction of a protective $\beta_{2}-\mathrm{AR} / \mathrm{G} \alpha_{\mathrm{S}} / \mathrm{PKA}$ signaling axis with SLP to ascertain whether signaling changes were PI3K-dependent (by sustained cotreatment with wortmannin), and whether the downstream PKA target Rho kinase (ROCK) participates in subsequent cardioprotection (by acute treatment with fasudil). A protected phenotype was evident after 5 days of OR agonism (using morphine) in association with increased membrane versus reduced cytosolic levels of total and phosphorylated $\beta_{2}$-ARs; increased membrane and cytosolic expression of 52 and $46 \mathrm{kDa}$
\end{abstract}

$\mathrm{G} \alpha_{\mathrm{S}}$ isoforms, respectively; and increased phosphorylation of PKA and Akt. Nonetheless, functional sensitivities of $\beta_{2}$-ARs and adenylyl cyclase were unchanged based on concentrationresponse analyses for formoterol, fenoterol, and 6-[3(dimethylamino)propionyl]-forskolin. Protection with SLP was not modified by ROCK inhibition, and changes in $\beta_{2}-\mathrm{AR}, \mathrm{G} \alpha_{\mathrm{s}}$, and PKA expression appeared insensitive to PI3K inhibition, although 5 days of wortmannin alone exerted unexpected effects on signaling (also increasing membrane $\beta_{2}$-AR and PKA expression/phosphorylation and $\mathrm{G} \alpha_{\mathrm{s}}$ levels). In summary, sustained OR agonism upregulates cardiac membrane $\beta_{2}$-AR expression and phosphorylation in association with increased $\mathrm{G} \alpha$ s subtype levels and PKA phosphorylation. While Akt phosphorylation was evident, $\mathrm{PI} 3 \mathrm{~K}$ activity appears nonessential to OR upregulation of the $\beta_{2}$-AR signal axis. This opioidergic remodeling of $\beta_{2}$-AR signaling may explain $\beta_{2}-\mathrm{AR}, \mathrm{G} \alpha_{\mathrm{s}}$, and PKA dependence of SLP protection.

\section{Introduction}

The novel sustained ligand-activated preconditioning (SLP) response (Peart and Gross, 2004b) induces powerful and prolonged ischemic tolerance, with notable effects in aged (Peart and Gross, 2004a) and diabetic hearts that are typically refractory to conventional cardioprotective stimuli (Headrick et al., 2015). Additionally, this response is efficacious in the presence of chronic (4 week) $\beta_{1}$-adrenoceptor (AR) blockade (See Hoe et al., 2016), supporting robustness in the presence of common cardiovascular therapies. The mechanistic basis of this powerful protective phenomenon remains unclear,

L.E.S.H. was the recipient of a National Heart Foundation of Australia Postgraduate Scholarship. J.N.P. was the recipient of an Australian Research Council Future Fellowship (FT100100695).

${ }^{1}$ Current affiliation: Critical Care Research Group, University of Queensland and the Prince Charles Hospital, Brisbane, Australia.

${ }^{2}$ Current affiliation: Department of Biochemistry and Molecular Biology, Infection and Immunity Program, Monash Biomedicine Discovery Institute, Monash University, Clayton, Australia.

https://doi.org/10.1124/jpet.118.251660.

S This article has supplemental material available at jpet.aspetjournals.org. although initial pharmacological interrogation suggested some phosphoinositide 3-kinase (PI3K) involvement during prolonged $\delta$-opioid receptor (OR) agonism while a $\beta_{2}-\mathrm{AR} / \mathrm{G}_{\mathrm{s}}$ alpha subunit $\left(\mathrm{G} \alpha_{\mathrm{s}}\right) /$ protein kinase $\mathrm{A}(\mathrm{PKA})$-dependent pathway contributed to subsequent acute protection (Peart and Gross, 2006). $\beta$-AR signaling involvement is congruent with roles for these receptors in protective responses such as ischemic preconditioning (Cross et al., 1999; Lochner et al., 1999; Zheng et al., 2004; Tong et al., 2005; Salie et al., 2011, 2012). Sustained OR agonism may modify the expression of and interactions between elements of the $\beta_{2}-\mathrm{AR} / \mathrm{G} \alpha_{\mathrm{s}} / \mathrm{PKA}$ pathway to promote a $\beta_{2}$-AR-mediated protective response to catecholamines released during ischemia/reperfusion (I/R) (Schömig et al., 1984; Kurz et al., 1995). Interestingly, ORs and $\beta_{2}$-ARs can also form oligomers in other cell types (Jordan et al., 2001), which could contribute to $\beta_{2}-\mathrm{AR} / \mathrm{G} \alpha_{\mathrm{s}} / \mathrm{PKA}$ dependence of opioidergic SLP (although OR activity generally counters cardiac effects of $\beta$-ARs). We also report protective crosstalk between ORs and adenosine receptors (Peart and Gross, 2003), a response involving EGFR transactivation (Williams-Pritchard et al., 2011). The protective $\delta$-OR could

ABBREVIATIONS: AC, Adenylyl cyclase; Akt, protein kinase B; AR, adrenoceptor; $\alpha_{\mathrm{s}}, \mathrm{G}_{\mathrm{s}}$ alpha subunit; $\mathrm{G} \alpha_{\mathrm{s}}-\mathrm{L}, \mathrm{G}, \mathrm{s}$ alpha subunit long variant; $\mathrm{G} \alpha_{\mathrm{s}} \mathrm{S}, \mathrm{G}_{\mathrm{s}}$ alpha subunit short variant; GPCR, G protein-coupled receptor; I/R, ischemia/reperfusion; OR, opioid receptor; phospho, phosphorylated; PI3K, phosphoinositide 3-kinase; PKA, protein kinase A; P/T, phosphorylated/total; ROCK, Rho kinase; SLP, sustained ligandactivated preconditioning. 
thus interact in different ways with multiple G proteincoupled receptor (GPCR) systems in mediation of cardioprotection. Well-established deterioration of the $\beta$-AR signaling system with disease and aging (Zheng et al., 2004; Tong et al., 2005; Ma and Pei, 2007; Grimm and Brown, 2010; Bernstein et al., 2011; Xiang, 2011) could in turn contribute to impaired ischemic tolerance and protective responses to ORs (Peart et al., 2007, 2014). This preconditioning effect of sustained OR agonism could also contribute to mitigation of the cardiac impacts of coronary artery disease in chronic opioid users (Marmor et al., 2004). Nonetheless, the mechanistic details of the novel SLP response remain unclear, and how OR agonism influences the $\beta_{2}-\mathrm{AR} / \mathrm{G} \alpha_{\mathrm{s}} / \mathrm{PKA}$ signal axis is unknown. Therefore, we investigated subcellular expression and phosphorylation of $\beta_{2}$-ARs, PKA and protein kinase $\mathrm{B}$ (Akt), and expression of $\mathrm{G} \alpha_{\mathrm{s}}$ subtypes after 24 hours and 5 days of OR-dependent SLP induction, and at 10 days after stimulus withdrawal. Functional sensitivities to $\beta_{2}-\mathrm{AR}$ and adenylyl cyclase (AC) activation were assessed, the role of PI3K in mediating molecular changes during SLP induction was tested by cotreatment with wortmannin, and involvement of the PKA target Rho kinase (ROCK) in mediating protection during subsequent I/R was tested by acute treatment with fasudil.

\section{Materials and Methods}

Animals. Investigations for this project conformed to the guidelines of the Animal Ethics Committee of Griffith University (MSC/04/13AEC). Hearts were isolated from young male (12 weeks) C57/Bl6 mice that were either vehicle (control) or SLP treated ( \pm wortmannin).

Experimental Groups. To assess mechanisms underlying SLPmediated cardioprotection and the role of the $\beta_{2}$-AR axis, four groups were investigated (control, SLP, control + wortmannin, and SLP + wortmannin) at three distinct time points (early and late induction, and after 10 days of withdrawal of the OR stimulus). Mice were anesthetized with an isoflurane $(3 \%)$ anesthetic drop jar, a small incision was made at the base of the neck, and vehicle (control) or slowrelease morphine ( $25 \mathrm{mg}$ ) pellets (National Institute of Drug Abuse) were inserted in the dorsal subcutaneous space before the site was closed with $9 \mathrm{~mm}$ wound clips. A subset of mice was cotreated with wortmannin to test the effects of PI3K inhibition on induction of SLP. Osmotic minipumps (model 1007D; Alzet, Cupertino, CA) containing wortmannin (releasing $30 \mu \mathrm{g} / \mathrm{kg}$ per day) were implanted subcutaneously with vehicle or morphine pellets. We have previously used this dose of wortmannin to abolish induction of SLP in the mouse, with associated shifts in Akt (Peart and Gross, 2006), and similarly we have previously used in vivo rat models of infarction (Gross et al., 2004, 2005). Implants were left in place for 24 hours or 5 days before cardiac analyses. For the 10 days of withdrawal group, pellets were surgically removed (under isoflurane anesthesia) after 5 days of implantation, incisions were closed with wound clips, and mice were injected intraperitoneally with naloxone $(7 \mathrm{mg} / \mathrm{kg})$ to facilitate a reduction in OR activity. Hearts from the 10 days of withdrawal group were then assessed 10 days later (Peart et al., 2011). At the end of each protocol (24 hours, 5 days, and 10 days after withdrawal), hearts were excised for molecular analysis or Langendorff perfusion to determine I/R tolerance or sensitivities to $\beta$-AR and AC activation (See Fig. 1).

Myocardial Protein Expression Analyses. To examine changes in protein expression, phosphorylation, and localization, cardiac tissue fractions were assessed using western blotting as previously described (Budiono et al., 2016). Left ventricles were isolated and frozen in liquid $\mathrm{N}_{2}$ before storage at $-80^{\circ} \mathrm{C}$. Samples were homogenized using a glass dounce in lysis buffer containing

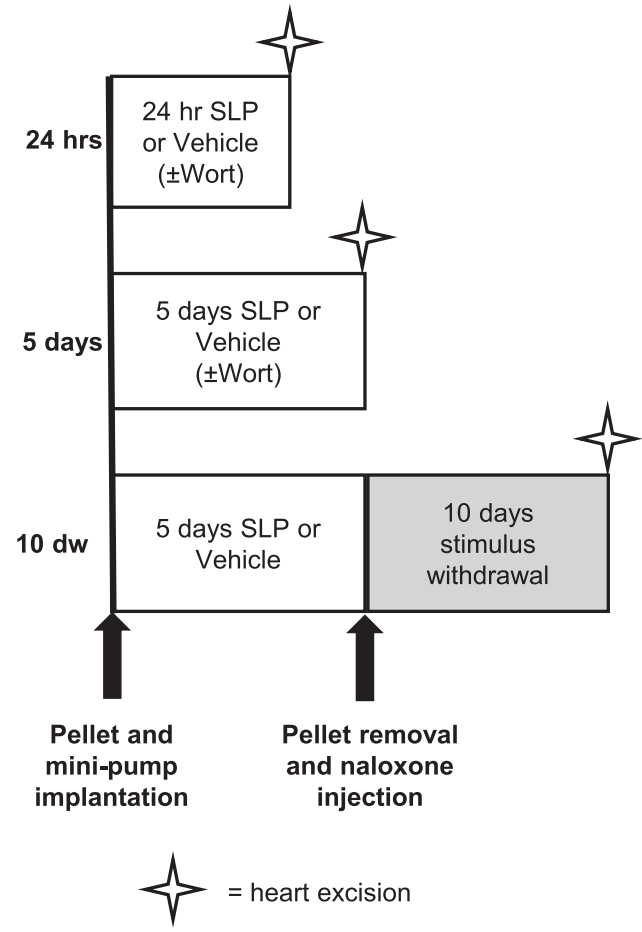

Fig. 1. Schematic outline of the experimental groups and induction of SLP (10 dw, 10 days after withdrawal).

protease and phosphatase inhibitors: 4-morpholinepropanesulfonic acid, $20 \mathrm{mM}$; EGTA, $2 \mathrm{mM}$; EDTA, $5 \mathrm{mM}$; sodium fluoride, $30 \mathrm{mM}$; $\beta$-glycerophosphate, $40 \mathrm{mM}$; sodium tetra-pyrophosphate, $20 \mathrm{mM}$; leupeptin, $0.01 \mathrm{mM}$; pepstatin A, $0.005 \mathrm{mM}$; benzamidine, $3 \mathrm{mM}$; phenylmethanesulfonyl fluoride, $1 \mathrm{mM}$; and sodium orthovanadate, $1 \mathrm{mM}$. Samples were centrifuged at $4^{\circ} \mathrm{C}$ for 10 minutes at $700 \mathrm{~g}$ to remove cellular debris. To obtain a cytosolic fraction, hearts were spun at $4^{\circ} \mathrm{C}$ for 90 minutes at $100,000 \mathrm{~g}$. The supernatant collected was the cytosolic fraction, and the pellet was resuspended in lysis buffer containing $0.1 \%$ Triton- $\mathrm{X}$ to obtain the membrane-enriched fraction (Peart et al., 2007, 2014). Protein contents were determined using commercial bicinchoninic acid protein assay kits (Pierce Biotechnology, Inc.) according to the manufacturer's instructions. For relative expression of cytosolic and membrane markers in each fraction, please see Supplemental Fig. 1.

Briefly, each hand-cast $10 \%$ acrylamide gel was loaded with $20 \mu \mathrm{g}$ protein per well, which was separated at $150 \mathrm{~V}$ for 60 minutes. Proteins were transferred to polyvinylidene difluoride fluorescent membranes ( $75 \mathrm{~V}$ for 2.5 hours) and blocked with Odyssey Fish Serum for 2 hours. Blots were incubated with the following primary antibodies overnight at $4^{\circ} \mathrm{C}$ with gentle agitation: Akt 1:1000 (Cell Signaling Technology), phosphorylated (phospho)-Akt 1:1000 (Cell Signaling Technology), $\beta_{2}$-AR 1:750 (Santa Cruz Biotechnology), phospho- $\beta_{2}$-AR 1:750 (Santa Cruz Biotechnology), PKA 1:1000 (Cell Signaling Technology), phospho-PKA 1:1000 (Cell Signaling Technology), G $\alpha_{\mathrm{s}}$ 1:750 (Santa Cruz Biotechnology), and glyceraldehyde-3phosphate dehydrogenase 1:5000 (Santa Cruz Biotechnology). After four washes ( 5 minutes each) with Tris-buffered saline and $1 \%$ Tween 20 followed by a 10-minute wash in Tris-buffered saline, blots were incubated in the dark with fluorescently tagged secondary antibody. Blots were visualized and protein was quantified using a Licor Odyssey Infrared Imaging System (Millenium Science, Mulgrave, Australia). Following protein quantification, protein densities were normalized to internal standards on each gel, and expressed relative to glyceraldehyde-3-phosphate dehydrogenase. These data are presented in Tables 1-4, and representative blots are presented in Supplemental Fig. 2. The internal standard used was an untreated, 
TABLE 1

$\beta_{2}$-AR expression changes during SLP induction and withdrawal

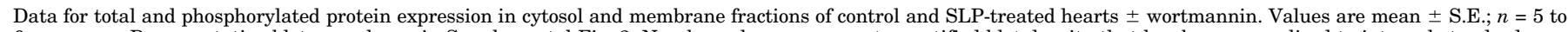
6 per group. Representative blots are shown in Supplemental Fig. 2. Numbers shown represent quantified blot density that has been normalized to internal standard.

\begin{tabular}{|c|c|c|c|c|c|c|c|c|}
\hline & \multirow{2}{*}{ Time } & \multirow{2}{*}{ Group } & \multicolumn{2}{|c|}{ Total $\beta_{2}$-AR } & \multicolumn{2}{|c|}{ Phospho $\beta_{2}$-AR } & \multicolumn{2}{|c|}{$\mathrm{P} / \mathrm{T}$ Ratio } \\
\hline & & & Cytosol & Membrane & Cytosol & Membrane & Cytosol & Membrane \\
\hline \multirow[t]{6}{*}{ No Wort. } & \multirow[t]{2}{*}{$24 \mathrm{~h}$} & Control $(n=6)$ & $1.05 \pm 0.03$ & $1.01 \pm 0.15$ & $0.97 \pm 0.08$ & $0.98 \pm 0.06$ & $0.92 \pm 0.08$ & $0.98 \pm 0.08$ \\
\hline & & $\operatorname{SLP}(n=6)$ & $0.68 \pm 0.12 *$ & $1.78 \pm 0.14^{*}$ & $0.95 \pm 0.05$ & $1.39 \pm 0.07^{*}$ & $1.27 \pm 0.08^{*}$ & $0.81 \pm 0.06$ \\
\hline & \multirow[t]{2}{*}{$5 \mathrm{~d}$} & Control $(n=6)$ & $0.92 \pm 0.13$ & $1.03 \pm 0.11$ & $0.97 \pm 0.07$ & $0.97 \pm 0.11$ & $1.10 \pm 0.12$ & $0.97 \pm 0.07$ \\
\hline & & $\operatorname{SLP}(n=6)$ & $0.64 \pm 0.08$ & $1.61 \pm 0.14^{*}$ & $0.91 \pm 0.06$ & $1.32 \pm 0.11^{*}$ & $1.45 \pm 0.11$ & $0.82 \pm 0.05$ \\
\hline & \multirow[t]{2}{*}{$10 \mathrm{dw}$} & Control $(n=6)$ & $1.00 \pm 0.06$ & $0.92 \pm 0.13$ & $0.89 \pm 0.15$ & $1.05 \pm 0.16$ & $0.81 \pm 0.03$ & $1.20 \pm 0.91$ \\
\hline & & $\operatorname{SLP}(n=5)$ & $1.1 \pm 0.13$ & $0.87 \pm 0.16$ & $1.18 \pm 0.13$ & $0.90 \pm 0.14$ & $1.13 \pm 0.10^{*}$ & $1.11 \pm 0.10$ \\
\hline \multirow[t]{4}{*}{ Wort. treated } & \multirow[t]{2}{*}{$24 \mathrm{~h}$} & Wort. $(n=6)$ & $0.62 \pm 0.06^{*}$ & $1.24 \pm 0.09$ & $1.03 \pm 0.09$ & $1.10 \pm 0.13$ & $1.58 \pm 0.14^{*}$ & $0.92 \pm 0.1$ \\
\hline & & SLP + Wort. $(n=6)$ & $0.64 \pm 0.06$ & $1.97 \pm 0.22 \#$ & $0.73 \pm 0.1$ & $1.31 \pm 0.27$ & $1.10 \pm 0.06 \#$ & $0.72 \pm 0.16$ \\
\hline & \multirow[t]{2}{*}{$5 \mathrm{~d}$} & Wort. $(n=6)$ & $0.82 \pm 0.10$ & $2.59 \pm 0.33^{*}$ & $0.84 \pm 0.09$ & $2.11 \pm 0.30 *$ & $0.98 \pm 0.11$ & $0.85 \pm 0.05$ \\
\hline & & SLP + Wort. $(n=6)$ & $0.65 \pm 0.14$ & $1.51 \pm 0.14 \#$ & $1.23 \pm 0.14 \#$ & $1.24 \pm 0.20 \#$ & $1.77 \pm 0.15 \#$ & $0.76 \pm 0.08$ \\
\hline
\end{tabular}

$\mathrm{dw}$, days of withdrawal; Wort., wortmannin.

$* P \leq 0.05$ vs. control; $\uparrow P \leq 0.05$ vs. SLP; $\# P \leq 0.05$ vs. wortmannin.

nonperfused mouse heart that underwent the same subcellular fractionation protocol as listed previously.

Langendorff Perfusions. Hearts were isolated and perfused for assessment of $\mathrm{I} / \mathrm{R}$ tolerance and changes in functional sensitivity to $\beta_{2}$-AR agonism or AC activation. Mice were anesthetized with sodium pentobarbital ( $60 \mathrm{mg} / \mathrm{kg}$, i.p.), the heart was excised, and the aorta was cannulated for Langendorff perfusion of the coronary circulation, as described previously (Headrick et al., 2003; Peart et al., 2007; Reichelt et al., 2009). All hearts were perfused at a constant hydrostatic pressure of $80 \mathrm{~mm} \mathrm{Hg}$ with modified Krebs-Henseleit buffer bubbled with $95 \% \mathrm{O}_{2} / 5 \% \mathrm{CO}_{2}$ at $37^{\circ} \mathrm{C}$ (giving a $\mathrm{pH}$ of 7.4 ), and containing $\mathrm{NaCl}$, $119 \mathrm{mM}$; glucose, $11 \mathrm{mM}$; $\mathrm{NaHCO}_{3}, 22 \mathrm{mM}$; KCl, $4.7 \mathrm{mM} ; \mathrm{MgCl}_{2}$, $1.2 \mathrm{mM}$; $\mathrm{KH}_{2} \mathrm{PO}_{4}, 1.2 \mathrm{mM}$; EDTA, $0.5 \mathrm{mM}$, and $\mathrm{CaCl}_{2}, 2.5 \mathrm{mM}$. Contractile function was monitored by a fluid-filled balloon in the left ventricle, inflated to generate an end-diastolic pressure of $\sim 5 \mathrm{~mm} \mathrm{Hg}$. An ultrasonic flow probe positioned proximal to the aortic cannula and connected to a T206 flowmeter (Transonic Systems Inc., Ithaca, NY) measured coronary flow. Ventricular pacing was performed at 420 beats per minute using an SD9 stimulator (Grass Instruments, Quincy, MA). An 8/s MacLab system (ADInstruments Pty Ltd., Castle Hill, Australia) connected to an Apple iMac computer was used to record functional data at $1 \mathrm{KHz}$. Variables measured included peak systolic pressure, end-diastolic pressure, + and - differential of ventricular pressure development, coronary flow, and heart rate.

Ischemic Tolerance and Role of ROCK in SLP Protection. After 20-minute stabilization, Langendorff-perfused hearts were switched to ventricular pacing at 420 beats/min. Baseline measurements were made, followed by 25 minutes of global normothermic ischemia and 45-minute reperfusion. Ventricular pacing was stopped during ischemia and resumed after 2-minute reperfusion. Extent of cell damage and death in response to $\mathrm{I} / \mathrm{R}$ was assessed via enzymatic assay of total lactate dehydrogenase efflux throughout reperfusion (See Hoe et al., 2016). Hearts were excluded from the study if they met one or more of the following criteria: 1 ) coronary flow $>5 \mathrm{ml} / \mathrm{min}$ (near maximal dilation or aortic tear), 2) unstable contractile function, 3) significant arrhythmias, or 4) left ventricular systolic pressure below $100 \mathrm{~mm} \mathrm{Hg}$. In a subset of hearts, the ROCK inhibitor fasudil (fasudil hydrochloride, $5 \mu \mathrm{M}$ final concentration) (Hamid et al., 2007) was acutely administered for 10 minutes pre- and postischemia (see Fig. 2).

Concentration-Response Analysis of $\beta_{2}$-AR Agonists and AC Activation. Hearts were prepared as previously described with the addition of $2 \mathrm{mM}$ pyruvate to perfusion fluid to ensure stable contractile function (previously shown to eliminate the phenomenon of functional cycling in murine hearts) (Sutherland et al., 2003); with hearts unpaced to allow assessment of chronotropic effects of applied drugs. After 20-minute equilibration, concentration-response curves were obtained for the following agents; the long-acting $\beta_{2}$-AR agonist formoterol $\quad[( \pm)-(R, R)-N$-[2-hydroxy-5-[1-hydroxy-2-[[2-(4methoxyphenyl)-1-methylethyl]amino] ethyl]phenyl] formamide], the selective $\beta_{2}$-AR-coupled $\mathrm{G} \alpha_{\mathrm{s}}$ signaling agonist fenoterol [2-(3,5dihydroxyphenyl)-2-hydroxy-2'-(4-hydroxyphenyl)-1'-methyldiethylamine hydrobromide], and the AC activator 6-[3-(dimethylamino)propionyl]-forskolin. Drugs were delivered via cannula at $1 \%-3 \%$ of coronary flow rate using an infusion pump (Pump 22; Harvard Instruments), with incremental increases after 5 minutes at each concentration.

\section{TABLE 2}

$\mathrm{G} \alpha_{\mathrm{s}}$ expression changes (long and short variants) during SLP induction and withdrawal

Data for protein expression changes in cytosolic and membrane fractions of control and SLP-treated hearts \pm wortmannin; $n=5$ to 6 per group. Values are mean \pm S.E. Representative blots are shown in Supplemental Fig. 2. Numbers shown represent quantified blot density that has been normalized to internal standard.

\begin{tabular}{|c|c|c|c|c|c|c|}
\hline & \multirow{2}{*}{ Time } & \multirow{2}{*}{ Group } & \multicolumn{2}{|c|}{ Cytosol } & \multicolumn{2}{|c|}{ Membrane } \\
\hline & & & $52 \mathrm{kDa}$ & $46 \mathrm{kDa}$ & $52 \mathrm{kDa}$ & $46 \mathrm{kDa}$ \\
\hline \multirow[t]{6}{*}{ No Wort. } & \multirow[t]{2}{*}{$24 \mathrm{~h}$} & Control $(n=6)$ & $1.10 \pm 0.07$ & $0.93 \pm 0.08$ & $0.88 \pm 0.12$ & $1.08 \pm 0.13$ \\
\hline & & $\operatorname{SLP}(n=6)$ & $0.96 \pm 0.05$ & $0.99 \pm 0.08$ & $1.16 \pm 0.09$ & $1.48 \pm 0.15$ \\
\hline & \multirow{2}{*}{$5 \mathrm{~d}$} & Control $(n=6)$ & $0.92 \pm 0.12$ & $1.02 \pm 0.10$ & $0.96 \pm 0.09$ & $1.03 \pm 0.07$ \\
\hline & & $\operatorname{SLP}(n=6)$ & $1.17 \pm 0.12$ & $1.63 \pm 0.15^{*}$ & $1.56 \pm 0.15^{*}$ & $1.19 \pm 0.05$ \\
\hline & \multirow[t]{2}{*}{$10 \mathrm{dw}$} & Control $(n=6)$ & ND & $0.91 \pm 0.10$ & $0.99 \pm 0.21$ & $1.05 \pm 0.26$ \\
\hline & & $\operatorname{SLP}(n=5)$ & ND & $0.91 \pm 0.10$ & $0.84 \pm 0.18$ & $1.14 \pm 0.34$ \\
\hline \multirow[t]{4}{*}{ Wort. treated } & \multirow[t]{2}{*}{$24 \mathrm{~h}$} & Wort. $(n=6)$ & $1.26 \pm 0.06$ & $0.94 \pm 0.05$ & $1.00 \pm 0.11$ & $1.08 \pm 0.13$ \\
\hline & & SLP + Wort. $(n=6)$ & $1.18 \pm 0.12$ & $0.77 \pm 0.10$ & $1.02 \pm 0.15$ & $1.43 \pm 0.12$ \\
\hline & \multirow[t]{2}{*}{$5 \mathrm{~d}$} & Wort. $(n=6)$ & $1.03 \pm 0.08$ & $1.64 \pm 0.34$ & $2.33 \pm 0.28^{*}$ & $1.84 \pm 0.16^{*}$ \\
\hline & & SLP + Wort. $(n=6)$ & $0.78 \pm 0.07$ & $1.20 \pm 0.21$ & $1.27 \pm 0.18 \#$ & $0.98 \pm 0.12 \#$ \\
\hline
\end{tabular}


TABLE 3

PKA expression changes with SLP induction and withdrawal

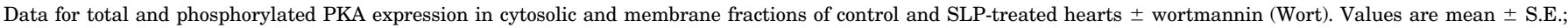

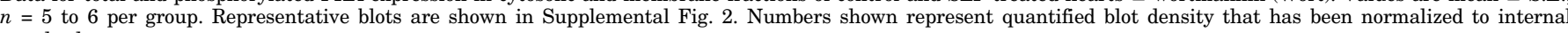
standard.

\begin{tabular}{|c|c|c|c|c|c|c|c|c|}
\hline & \multirow{2}{*}{ Time } & \multirow{2}{*}{ Group } & \multicolumn{2}{|c|}{ Total PKA } & \multicolumn{2}{|c|}{ Phospho-PKA } & \multicolumn{2}{|c|}{ P/T Ratio } \\
\hline & & & Cytosol & Membrane & Cytosol & Membrane & Cytosol & Membrane \\
\hline \multirow[t]{6}{*}{ No Wort. } & \multirow[t]{2}{*}{$24 \mathrm{~h}$} & Control $(n=6)$ & $0.97 \pm 0.03$ & $1.07 \pm 0.06$ & $0.96 \pm 0.06$ & $1.00 \pm 0.09$ & $0.97 \pm 0.04$ & $0.95 \pm 0.07$ \\
\hline & & $\operatorname{SLP}(n=6)$ & $0.93 \pm 0.04$ & $1.19 \pm 0.07$ & $1.06 \pm 0.09$ & $1.03 \pm 0.15$ & $1.16 \pm 0.06^{*}$ & $0.72 \pm 0.07^{*}$ \\
\hline & \multirow[t]{2}{*}{$5 \mathrm{~d}$} & Control $(n=6)$ & $1.06 \pm 0.07$ & $1.02 \pm 0.07$ & $1.00 \pm 0.03$ & $0.91 \pm 0.10$ & $0.96 \pm 0.05$ & $0.91 \pm 0.06$ \\
\hline & & $\operatorname{SLP}(n=6)$ & $1.04 \pm 0.09$ & $1.17 \pm 0.09$ & $0.87 \pm 0.03^{*}$ & $1.70 \pm 0.18^{*}$ & $0.84 \pm 0.20$ & $1.61 \pm 0.18^{*}$ \\
\hline & \multirow[t]{2}{*}{$10 \mathrm{dw}$} & Control $(n=6)$ & $0.99 \pm 0.03$ & $1.51 \pm 0.96$ & $1.04 \pm 0.09$ & $1.04 \pm 0.07$ & $1.07 \pm 0.04$ & $0.91 \pm 0.21$ \\
\hline & & $\operatorname{SLP}(n=5)$ & $1.08 \pm 0.05$ & $1.52 \pm 0.85$ & $1.20 \pm 0.08$ & $0.85 \pm 0.03^{*}$ & $1.18 \pm 0.07$ & $0.55 \pm 0.12$ \\
\hline \multirow[t]{4}{*}{ Wort. treated } & \multirow[t]{2}{*}{$24 \mathrm{~h}$} & Wort. $(n=6)$ & $1.03 \pm 0.08$ & $0.87 \pm 0.06$ & $1.24 \pm 0.06$ & $1.25 \pm 0.15$ & $1.26 \pm 0.07^{*}$ & $1.43 \pm 0.12^{*}$ \\
\hline & & SLP + Wort. $(n=6)$ & $0.93 \pm 0.06$ & $1.07 \pm 0.08$ & $1.18 \pm 0.11$ & $1.40 \pm 0.28$ & $1.18 \pm 0.10$ & $1.18 \pm 0.17 \dagger$ \\
\hline & \multirow[t]{2}{*}{$5 \mathrm{~d}$} & Wort. $(n=6)$ & $0.97 \pm 0.11$ & $1.97 \pm 0.34^{*}$ & $0.88 \pm 0.08$ & $2.74 \pm 0.39^{*}$ & $0.90 \pm 0.04$ & $1.56 \pm 0.25$ \\
\hline & & SLP + Wort. $(n=6)$ & $0.84 \pm 0.07$ & $1.29 \pm 0.22 \#$ & $1.00 \pm 0.13$ & $1.47 \pm 0.21 \#$ & $1.35 \pm 0.05 \dagger \#$ & $1.31 \pm 0.24$ \\
\hline
\end{tabular}

$\mathrm{dw}$, days of withdrawal; Wort., wortmannin.

$* P \leq 0.05$ vs. control; $\uparrow P \leq 0.05$ vs. SLP; $\# P \leq 0.05$ vs. wortmannin.

Statistical Analysis. All values are expressed as mean \pm S.E. Differences between groups were tested via one-way ANOVA (or $t$ test where appropriate), with Newman-Keuls post hoc test applied when significant effects were detected. Significant differences were accepted for $P<0.05$. All data analyses were performed using Prism software (GraphPad Software, Inc., La Jolla CA).

\section{Results}

\section{SLP-Mediated Cardioprotection}

There was no significant improvement in ischemic tolerance after 24 hours of SLP induction, whereas significant protection was evident after 5 days, including improved postischemic recoveries of end-diastolic pressure and left ventricular developed pressure (Fig. 3). SLP-mediated cardioprotection was eliminated after a 10-day period of stimulus withdrawal, which normalized ischemic tolerance in these hearts.

\section{Impact of SLP Induction on $\boldsymbol{\beta}_{\mathbf{2}}-\mathrm{AR} / \mathrm{G}_{\mathrm{a}}$ s/PKA Signaling Elements and Akt}

Our prior work suggests a role for PI3K signaling in $\delta$-OR-dependent induction of SLP, leading in turn to $\beta_{2}-\mathrm{AR}-$, $\mathrm{G} \alpha_{\mathrm{s}^{-}}$, and PKA-dependent protection during the mediation phase (Peart and Gross, 2006). Here, we show SLP induction triggers significant changes in myocardial expression/ localization of elements of the $\beta_{2}-\mathrm{AR} / \mathrm{G} \alpha_{\mathrm{s}} / \mathrm{PKA}$ signal axis.

$\boldsymbol{\beta}_{2}$-ARs (Table 1). An early shift in $\beta_{2}$-AR expression was evident at 24 hours, with a decline in cytosolic levels and increased membrane expression (consistent with possible trafficking to the membrane). Cytosolic fractions consistently expressed a single $\beta_{2}$-AR species at $\approx 68 \mathrm{kDa}$, compared with membrane $\beta_{2}$-AR expression that contained multiple bands at $\approx 90 \mathrm{kDa}$ (Hebert et al., 1998). Phosphorylated $\beta_{2}$-AR levels were also increased in the membrane fractions. The cytosolic $\beta_{2}$-AR phosphorylated/total (P/T) ratio was increased, due to reduced total cytosolic $\beta_{2}$-AR expression. Similar shifts were apparent after 5 days, although there was no significant change in cytosolic or membrane $\mathrm{P} / \mathrm{T}$ ratio. A 10-day withdrawal period largely countered these changes, although a modest increase in cytosolic $\mathrm{P} / \mathrm{T}$ ratio remained. Cotreatment with wortmannin throughout the SLP induction period did not block these changes, suggesting that PI3K signaling is not essential in this process. Curiously, wortmannin alone reduced total $\beta_{2}$-AR expression in cytosolic fractions after 24-hour treatment, contributing to an increased cytosolic $\beta_{2}$-AR P/T ratio. Additionally, 5 days of wortmannin treatment increased total and phosphorylated $\beta_{2}$-AR expression in the membrane fraction.

\section{TABLE 4}

Akt expression changes during SLP induction and withdrawal

Data for total and phosphorylated Akt expression changes in cytosolic and membrane fractions of control and SLP-treated hearts \pm wortmannin. Values are mean \pm S.E.; $n=$ 5 to 6 per group. Representative blots are shown in Supplemental Fig. 2. Numbers shown represent quantified blot density that has been normalized to internal standard.

\begin{tabular}{|c|c|c|c|c|c|c|c|c|}
\hline & Time & Group & \multicolumn{2}{|c|}{ Total Akt } & \multicolumn{2}{|c|}{ Phospho-Akt } & \multicolumn{2}{|c|}{ P/T Ratio } \\
\hline \multirow[t]{5}{*}{ No Wort. } & $24 \mathrm{~h}$ & Control $(n=6)$ & $1.01 \pm 0.06$ & $1.02 \pm 0.15$ & $0.96 \pm 0.15$ & $0.99 \pm 0.03$ & $0.98 \pm 0.12$ & $1.10 \pm 0.08$ \\
\hline & \multirow[t]{2}{*}{$5 \mathrm{~d}$} & Control $(n=6)$ & $0.99 \pm 0.04$ & $0.98 \pm 0.10$ & $0.92 \pm 0.11$ & $1.09 \pm 0.15$ & $0.92 \pm 0.05$ & $1.11 \pm 0.13$ \\
\hline & & $\operatorname{SLP}(n=6)$ & $1.05 \pm 0.04$ & $0.91 \pm 0.09$ & $1.17 \pm 0.15$ & $1.40 \pm 0.17$ & $1.27 \pm 0.13^{*}$ & $1.54 \pm 0.14^{*}$ \\
\hline & \multirow[t]{2}{*}{$10 \mathrm{dw}$} & Control $(n=6)$ & $0.94 \pm 0.06$ & $0.96 \pm 0.21$ & $0.99 \pm 0.06$ & $0.99 \pm 0.15$ & $1.11 \pm 0.07$ & $1.13 \pm 0.14$ \\
\hline & & $\operatorname{SLP}(n=5)$ & $0.84 \pm 0.07$ & $0.86 \pm 0.13$ & $1.07 \pm 0.07$ & $1.70 \pm 0.39$ & $1.23 \pm 0.08$ & $1.88 \pm 0.17 *$ \\
\hline \multirow{2}{*}{ Wort. treated } & \multirow{2}{*}{$5 \mathrm{~d}$} & Wort. $(n=6)$ & $1.18 \pm 0.06$ & $0.79 \pm 0.11$ & $1.42 \pm 0.16$ & $1.03 \pm 0.12$ & $1.17 \pm 0.06$ & $1.32 \pm 0.03$ \\
\hline & & SLP + Wort. $(n=6)$ & $1.11 \pm 0.05$ & $0.71 \pm 0.11$ & $1.83 \pm 0.17 \dagger$ & $1.26 \pm 0.17$ & $1.51 \pm 0.1 \#$ & $1.86 \pm 0.21 \#$ \\
\hline
\end{tabular}

$\mathrm{dw}$, days of withdrawal; Wort., wortmannin

$* P \leq 0.05$ vs. control; $\uparrow P \leq 0.05$ vs. SLP; $\# P \leq 0.05$ vs. wortmannin. 


\section{A I/R Tolerance (Fig. 3)}

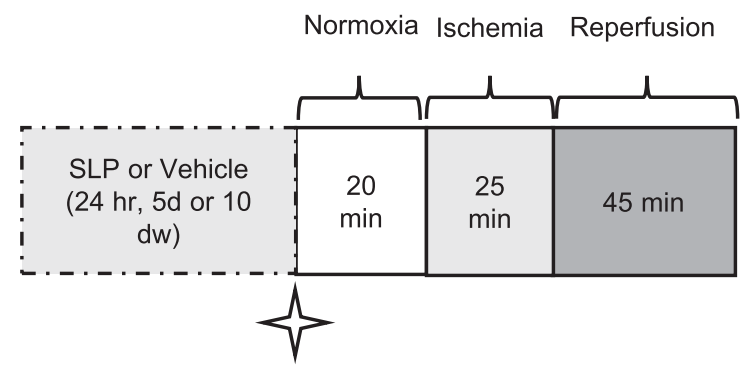

B Effect of ROCK Inhibition on SLP-mediated protection (Fig. 4)

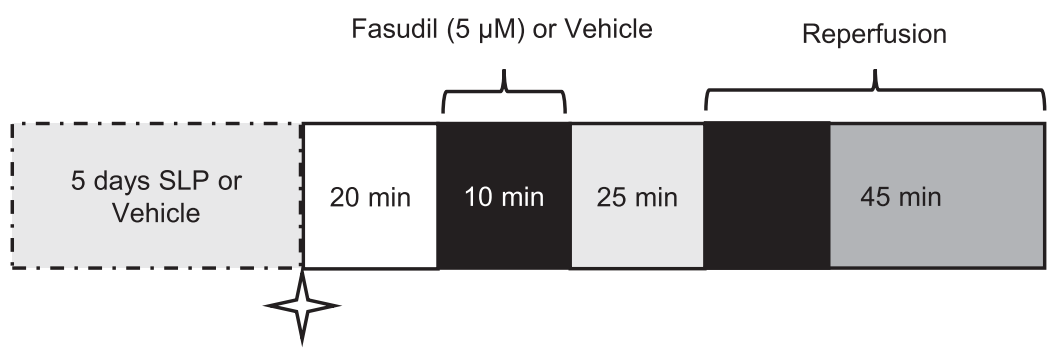

Fig. 2. Timeline for Langendorff perfusions to assess (A) ischemic tolerance after treatment with SLP for 24 hours and 5 days, and after stimulus withdrawal [10 days after withdrawal (10 dw)], and (B) the effect of ROCK inhibition on SLP-mediated protection.<smiles>O=C(O)C(=O)OC1CCC2CCC1C2</smiles>

$\mathbf{G} \boldsymbol{\alpha}_{\text {s }}$ Subtypes (Table 2). SLP led to differential changes in the expression of the long and short isoforms of the $\mathrm{G} \alpha \mathrm{s}$ protein. Specifically, after 5 days of SLP, the $46 \mathrm{kDa}$ isoform of $\mathrm{G} \alpha_{\mathrm{s}}\left[\mathrm{G} \alpha_{\mathrm{s}}\right.$ short variant $\left.\left(\mathrm{G} \alpha_{\mathrm{s}}-\mathrm{S}\right)\right]$ was increased in cytosolic fractions, whereas the $52 \mathrm{kDa}$ isoform [G $\alpha_{\mathrm{s}}$ long variant $\left.\left(\mathrm{G} \alpha_{\mathrm{s}}-\mathrm{L}\right)\right]$ was increased in membrane fractions. These changes in protein localization were reversed following 10 days of stimulus withdrawal. These responses to SLP were partly countered by wortmannin cotreatment. Wortmannin alone increased membrane expression of both the 52 and $46 \mathrm{kDa} \mathrm{G} \alpha_{\mathrm{s}}$ isoforms after 5 days of treatment.

PKA (Table 3). There were no alterations in PKA expression following SLP at either 24 hours or 5 days. However, an elevated cytosolic $\mathrm{P} / \mathrm{T} \mathrm{PKA}$ ratio and a reduced membrane $\mathrm{P} / \mathrm{T}$ ratio were evident early in SLP induction. After 5 days of SLP induction, a decline in cytosolic and an increase in membrane phospho-PKA were apparent, in association with an increased membrane $\mathrm{P} / \mathrm{T}$ ratio. These changes were reversed upon stimulus withdrawal. These SLP effects on phospho-PKA were not significantly altered by wortmannin. Wortmannin alone transiently increased cytosolic and membrane $\mathrm{P} / \mathrm{T}$ ratios at 24 hours, and increased total and phospho-PKA in membrane fractions after 5 days of treatment.

Akt (Table 4). SLP induction produced an early increase in membrane phospho-Akt levels and in the cytosolic $\mathrm{P} / \mathrm{T}$ ratio. After 5 days, relative phosphorylation of both cytosolic and membrane Akt was increased. Withdrawal generally reversed these responses; however, an elevated membrane $\mathrm{P} / \mathrm{T}$ ratio did persist. These SLP-dependent effects on Akt were not inhibited by cotreatment with wortmannin. Wortmannin alone did not significantly alter Akt expression or phosphorylation at 24 hours or 5 days.

\section{$\boldsymbol{\beta}_{2}$-AR and AC Responsiveness}

Protein expression and phosphorylation changes within the $\beta_{2}-\mathrm{AR} / \mathrm{G} \alpha_{\mathrm{s}} / \mathrm{PKA}$ pathway may influence myocardial sensitivities and responses to $\beta_{2}$-AR and adenylyl cyclase activities. To test for such outcomes, hearts from control and 5-day SLP-treated mice were exposed to increasing concentrations of formoterol (long-acting $\beta_{2}$-AR agonist), fenoterol (selective $\beta_{2}$-AR-coupled $\mathrm{G} \alpha_{\mathrm{s}}$ signaling agonist) or 6-[3(dimethylamino)propionyl]-forskolin (AC activator) (Table 5). Interestingly, despite significant changes in $\beta_{2}$-AR pathway components with SLP, this did not translate to altered functional (chronotropic and inotropic) responses or sensitivities to $\beta_{2}$-AR or AC activation. An exception was an elevated maximal heart rate (percentage of baseline) response to $\mathrm{AC}$ activation with 6-[3-(dimethylamino)propionyl]-forskolin in SLP hearts. SLP also reduced the Hill slope for fenoteroldependent changes.

\section{Role of ROCK in SLP-Dependent Cardioprotection}

Acute ROCK involvement during the I/R insult was evaluated in Langendorff-perfused hearts from control and SLP mice (Fig. 4). Baseline ex vivo cardiac function was unaltered by ROCK inhibition. Control hearts exhibited significant contractile dysfunction and cell death postischemia, an injury unchanged in the presence of fasudil (ROCK inhibitor). Treatment via SLP significantly improved postischemic functional recovery and limited cell death; however, ROCK inhibition did not alter this protective effect of SLP.

\section{Discussion}

The quest for adjunctive cardioprotective therapies has yet to yield a consistently protective intervention sufficiently efficacious in cardiac patients. We have shown that sustained $\delta$-OR agonism for 5 days can induce robust and prolonged protection against I/R injury in young and aged hearts, a phenotype termed sustained ligand-activated preconditioning (Peart et al., 2011). However, the molecular basis of SLP 
A

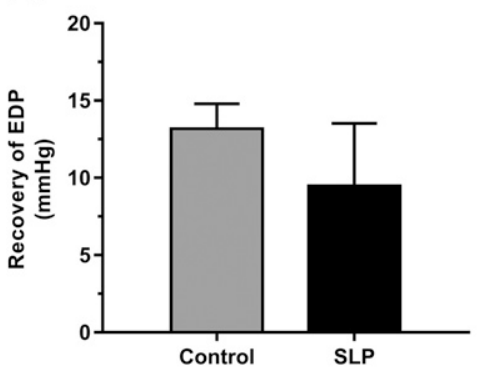

24 hrs

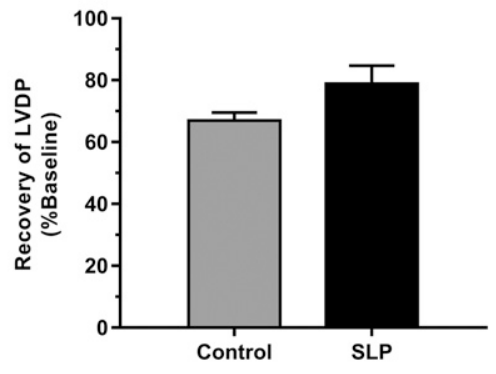

B

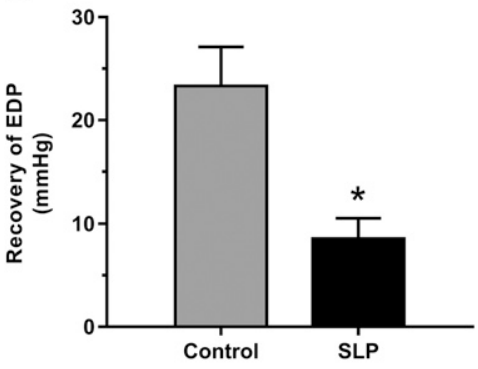

5 days

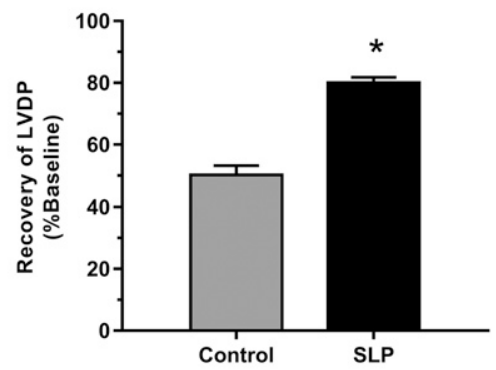

Fig. 3. Functional recovery after $I / R$ with SLP induction and withdrawal. Effects of 24 hours (A) and 5 days (B) of SLP induction, and 10 days of withdrawal (C) on I/R tolerance in ex vivo Langendorff-perfused hearts. Shown are recoveries for (left) end-diastolic pressure [(EDP), $\mathrm{mm}$ $\mathrm{Hg}]$ and (right) left ventricular developed pressure [(LVDP), \% baseline]. Values are mean \pm S.E. $; P \leq 0.05$ vs. control; $n=5-8$ per group.

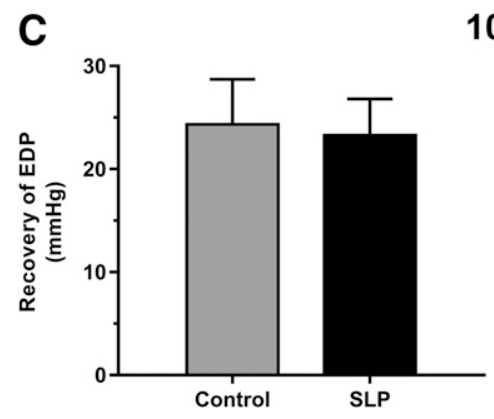

$10 \mathrm{dw}$

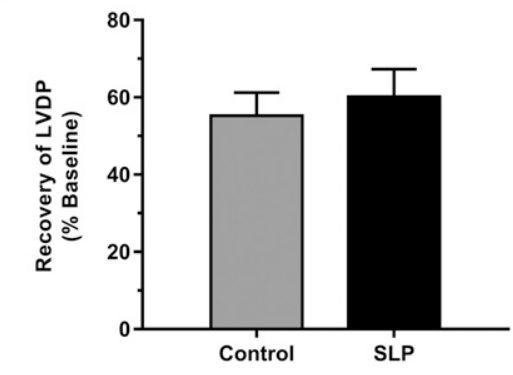

remains to be detailed. Prior experiments using signaling inhibitors implicate PI3K/wortmannin-sensitive signaling during the initial induction phase, and $\beta_{2}$-AR, $\mathrm{G} \alpha_{\mathrm{s}}$, and PKA involvement during subsequent mediation of protection (Peart et al., 2011). The current study thus tested whether this reflects PI3K-dependent upregulation of a protective $\beta_{2}$-AR/G $\alpha / \mathrm{PKA}$ signal axis. Data reveal significantly increased membrane $\beta_{2}$-AR expression and phosphorylation with SLP, together with increased $\mathrm{G} \alpha_{\mathrm{s}}$ subtype expression, and PKA and Akt phosphorylation, consistent with the novel induction of a $\beta_{2}$-AR signaling axis that may be engaged by local catecholamines during I/R. This OR-dependent signal remodeling appears selective, not modifying myocardial control by $\beta_{2}$-ARs or AC, and does not appear to require PI3K activity.

SLP-Dependent Shifts in $\boldsymbol{\beta}_{\mathbf{2}}$-AR Expression. Building on initial characterization of SLP (Peart and Gross, 2006; Peart et al., 2011), which suggested roles for $\mathrm{G} \alpha_{\mathrm{s}}, \beta_{2}$-AR, and PKA in mediation of protection, and PI3K in prior SLP induction, this study assessed expression changes in the $\beta_{2}$ AR/PKA signal axis during SLP induction, and their PI3K dependence. Early in SLP induction ( 24 hours), $\beta_{2}$-ARs appear to redistribute from cytosolic to membrane fractions, with increased phosphorylation of intracellular but not membrane receptors (Table 1). These changes generally persisted at 5 days of SLP induction, when the protected phenotype is evident (Peart and Gross, 2004b, 2006; Peart et al., 2011). The relevance of this shift in $\beta_{2}$-AR expression/localization in isolation is unclear, since no protection is evident after 24 hours (Fig. 3). The SLP phenotype arises after $3+$ days (Peart and Gross, 2004b), thus later additional changes, for example, parallel increases in $\mathrm{G} \alpha_{\mathrm{s}}$ expression and downstream PKA phosphorylation at 5 days, may be necessary for induction of $\mathrm{I} / \mathrm{R}$ tolerance. It is tempting to speculate that increased membrane versus intracellular $\beta_{2}$-AR expression reflects increased recycling to the membrane-receptor resensitization following internalization (Pippig et al., 1995). However, membrane levels of phosphorylated $\beta_{2}$-AR are increased at both 24 hours and 5 days, and phosphorylation promotes receptor internalization and $\beta$-arrestin binding to uncouple $\beta$-ARs from $\mathrm{G}$ proteins (Lohse et al., 1992; Ma and Pei, 2007). The antibody employed in this current study is likely unable to provide insight regarding internalization.

Specifically, the antibody used to detect $\beta_{2}$-AR phosphorylation targeted the Tyr 141 residue of the receptor. Phosphorylation at this site is reportedly directed by insulin (Valiquette et al., 1995); however, previous studies have shown conflicting results across different tissue and cell types regarding insulin-directed $\beta_{2}$-AR phosphorylation and downstream AC activity (Hickman and McElduff, 1990; Sager et al., 1990; van Tits et al., 1990; Davis et al., 1992; Hadcock et al., 1992; 
TABLE 5

Pharmacological analysis of cardiac responses to $\beta_{2}$-AR agonists and AC activation in control and SLP hearts Chronotropic, inotropic, and coronary flow responses to formoterol, fenoterol, and 6-[3-(dimethylamino)propionyl]-forskolin were assessed. Data were fit to concentration-response curves as detailed in Materials and Methods (employing both absolute functional changes and percentage of change from baseline). Derived parameters from each individual curve include: concentration inducing $50 \%$ maximal response $\left(\mathrm{EC}_{50}\right)$; the slope of the concentration-response curve (slope factor; Hill slope or coefficient reflecting steepness of the linear component of the response curve); and the peak response (maximal response). Values are mean \pm S.E.; $n=4-6$ per group.

\begin{tabular}{|c|c|c|c|c|c|c|c|}
\hline & & \multicolumn{2}{|c|}{ Formoterol ( $\beta_{2}$ - $\mathrm{AR}$ agonist $)$} & \multicolumn{2}{|c|}{ Fenoterol ( $\beta_{2}$-AR agonist) } & \multicolumn{2}{|c|}{ NKH 477 (AC activator) } \\
\hline & & Control & SLP & Control & SLP & Control & SLP \\
\hline \multicolumn{8}{|l|}{ Systolic pressure } \\
\hline \multirow[t]{2}{*}{$\mathrm{EC}_{50}$} & Absolute & $7.62 \pm 0.09$ & $7.56 \pm 0.04$ & $6.81 \pm 0.04$ & $6.86 \pm 0.06$ & $7.32 \pm 0.04$ & $7.14 \pm 0.06$ \\
\hline & $\%$ & $7.61 \pm 0.08$ & $7.59 \pm 0.04$ & $6.81 \pm 0.04$ & $6.82 \pm 0.06$ & $7.31 \pm 0.04$ & $7.15 \pm 0.06$ \\
\hline \multirow[t]{2}{*}{ Slope factor } & Absolute & $5.96 \pm 2.22$ & $2.55 \pm 0.27$ & $1.72 \pm 0.13$ & $1.78 \pm 0.17$ & $6.45 \pm 2.95$ & $2.81 \pm 0.32$ \\
\hline & $\%$ & $7.64 \pm 2.35$ & $2.55 \pm 0.27$ & $1.72 \pm 0.13$ & $1.76 \pm 0.16$ & $5.41 \pm 2.05$ & $5.57 \pm 1.56$ \\
\hline \multirow[t]{2}{*}{ Maximal response } & Absolute & $170 \pm 7$ & $190 \pm 12$ & $177 \pm 12$ & $169 \pm 5$ & $184 \pm 12$ & $163 \pm 6$ \\
\hline & $\%$ & $167 \pm 7$ & $166 \pm 20$ & $165 \pm 5$ & $149 \pm 10$ & $164 \pm 10$ & $137 \pm 7$ \\
\hline \multicolumn{8}{|l|}{ Heart rate } \\
\hline \multirow[t]{2}{*}{$\mathrm{EC}_{50}$} & Absolute & $7.15 \pm 2.25$ & $7.09 \pm 0.03$ & $6.88 \pm 0.11$ & $6.96 \pm 0.07$ & $7.20 \pm 0.07$ & $7.18 \pm 0.06$ \\
\hline & $\%$ & $7.77 \pm 0.07$ & $7.62 \pm 0.03$ & $6.88 \pm 0.11$ & $6.96 \pm 0.07$ & $7.20 \pm 0.07$ & $7.18 \pm 0.06$ \\
\hline \multirow[t]{2}{*}{ Slope factor } & Absolute & $2.65 \pm 0.51$ & $2.07 \pm 0.31$ & $1.74 \pm 0.19$ & $1.74 \pm 0.18$ & $1.65 \pm 0.19$ & $2.06 \pm 0.48$ \\
\hline & $\%$ & $3.03 \pm 0.83$ & $2.07 \pm 0.33$ & $1.54 \pm 0.19$ & $1.47 \pm 0.18$ & $1.65 \pm 0.19$ & $2.06 \pm 0.48$ \\
\hline \multirow[t]{2}{*}{ Maximal response } & Absolute & $554 \pm 25$ & $575 \pm 8$ & $571 \pm 4$ & $568 \pm 10$ & $588 \pm 5$ & $598 \pm 10$ \\
\hline & $\%$ & $156 \pm 6$ & $149 \pm 6$ & $159 \pm 6$ & $183 \pm 8^{*}$ & $158 \pm 6$ & $160 \pm 3$ \\
\hline \multicolumn{8}{|l|}{ Coronary flow } \\
\hline \multirow[t]{2}{*}{$\mathrm{EC}_{50}$} & Absolute & $7.66 \pm 0.10$ & $7.63 \pm 0.04$ & $7.16 \pm 0.05$ & $7.13 \pm 0.07$ & $7.23 \pm 0.02$ & $7.12 \pm 0.1$ \\
\hline & $\%$ & $7.72 \pm 0.10$ & $7.64 \pm 0.05$ & $7.16 \pm 0.05$ & $7.13 \pm 0.07$ & $7.24 \pm 0.02$ & $7.12 \pm 0.1$ \\
\hline \multirow[t]{2}{*}{ Slope factor } & Absolute & $1.88 \pm 0.11$ & $1.95 \pm 0.26$ & $1.67 \pm 0.18$ & $1.93 \pm 0.13$ & $2.31 \pm 0.35$ & $1.94 \pm 0.5$ \\
\hline & $\%$ & $1.94 \pm 0.11$ & $1.96 \pm 0.26$ & $1.67 \pm 0.18$ & $1.92 \pm 0.14$ & $2.31 \pm 0.35$ & $1.44 \pm 0.1^{*}$ \\
\hline \multirow[t]{2}{*}{ Maximal response } & Absolute & $4.31 \pm 0.5$ & $4.28 \pm 0.2$ & $4.42 \pm 0.1$ & $4.68 \pm 0.1$ & $4.98 \pm 0.3$ & $4.69 \pm 0.2$ \\
\hline & $\%$ & $164 \pm 12$ & $178 \pm 8$ & $180 \pm 12$ & $184 \pm 16$ & $183 \pm 17$ & $173 \pm 8$ \\
\hline
\end{tabular}

NKH 477, 6-[3-(dimethylamino)propionyl]-forskolin.

$* P \leq 0.05$ vs. respective control group.

Valiquette et al., 1995). Several groups identified that Tyr 141 phosphorylation of $\beta_{2}$-AR by insulin augments downstream AC activity (Hickman and McElduff, 1990; Sager et al., 1990; van Tits et al., 1990; Valiquette et al., 1995), and mutation of the Tyr 141 site attenuated insulin-promoted phosphorylation (Valiquette et al., 1995). Furthermore, $\beta_{2}$-AR can be phosphorylated by IGF-1R and the insulin receptor (CHO cells) at several phosphotyrosine sites, including Tyr 141 (Baltensperger et al., 1996). While we have not measured insulin levels or insulin-specific downstream effects in the current study, Olianas et al. (2011) proposed a mechanism of $\delta$-OR-mediated GLUT1 uptake of glucose through a signaling cascade involving Src activation of IGF-1R and subsequent PI3K $\alpha$, PDK1/2, and Akt activation. The apparent links between insulin signaling, $\beta_{2}$-AR, and $\delta$-OR activation in different cell types support the notion for further mechanistic clarification in the SLP phenotype. Additionally, modeling of the $\beta_{2}$-AR in the inactive conformation (Dror et al., 2009) highlights Tyr 141 as interacting with the ionic lock residues and formation of an intracellular loop $2 \alpha$-helix, potentially modifying interactions with $\mathrm{G} \alpha$. Furthermore, the intracellular loop $2 \alpha$-helix may have implication for basal activity of the $\beta_{2}$-AR.

SLP-Dependent Upregulation of $\mathbf{G} \alpha_{\mathbf{s}}$ Subtypes. Protective GPCR signaling involves interaction with $\mathrm{G}$ proteins to communicate extracellular messages to intracellular effectors such as phospholipase C, AC, and ion channels (Eschenhagen, 1993; Novotny and Svoboda, 1998; Novotny et al., 1999, 2001). In addition, activated $\mathrm{G} \alpha_{\mathrm{s}}$ acts as an intracellular messenger to modulate microtubule dynamics (Yu et al., 2009), key to cell morphology and intracellular signaling, and is implicated in preconditioning (Guo et al., 2017). Curiously, prior work implicated both stimulatory $\mathrm{G} \alpha_{\mathrm{s}}$ and inhibitory $\mathrm{G}_{\mathrm{i}}$ proteins in SLP protection (Peart and Gross, 2006), whereas acute morphine protection appears to be $\mathrm{G}_{\mathrm{i}}$ mediated. Napier et al. (1999) showed that 2-week morphine infusion increases cardiac $\mathrm{G} \alpha$ and $\mathrm{G}_{\mathrm{i}}$ expression. The present study demonstrates that 5 days of OR agonism increases cytosolic expression of $\mathrm{G} \alpha_{\mathrm{s}}-\mathrm{S}$ and membrane expression of $\mathrm{G} \alpha_{\mathrm{s}} \mathrm{L}$ (Table 2). These variants, $\mathrm{G} \alpha_{\mathrm{s}}-\mathrm{S}$ and $\mathrm{G} \alpha_{\mathrm{s}}-\mathrm{L}$, may possess functionally distinct roles and cellular localizations, and are modified with age, development, and shifts in thyroid status (Novotny and Svoboda, 1998; Novotny et al., 1999, 2001). The principal variant in the heart is $\mathrm{G} \alpha_{\mathrm{s}}-\mathrm{S}$, and an age-related decline in $\mathrm{G} \alpha_{\mathrm{s}}$ mRNA and protein expression has been observed (Urasawa et al., 1991; Miyamoto et al., 1994; Novotny and Svoboda, 1998). Improved ischemic tolerance in aged hearts with SLP (Peart and Gross, 2004a; Peart et al., 2007, 2011; Peart and Headrick, 2009) could thus involve increased expression of $\mathrm{G} \alpha_{\mathrm{s}}$ proteins. However, increased membrane-associated $\mathrm{G} \alpha_{\mathrm{S}}-\mathrm{L}$ may be more relevant to SLP protection, given evidence for preferential coupling of $\beta$-ARs to $\mathrm{G} \alpha_{\mathrm{s}}$-L, albeit in other cell types (Yagami, 1995), and the importance of membraneassociated $\mathrm{G} \alpha$ to signaling. Expression of $\mathrm{G} \alpha_{\mathrm{s}}-\mathrm{L}$ appears less sensitive to aging (Miyamoto et al., 1994; Shu and Scarpace, 1994; Johnson et al., 1995), or may increase (Urasawa et al., 1991). Regardless, OR-driven elevations in $\mathrm{G} \alpha_{\mathrm{s}}$ subtypes further support induction of a protective $\beta_{2}$-AR signal axis with sustained OR activity.

SLP-Dependent Upregulation of PKA Phosphorylation. The cAMP-dependent protein kinase PKA regulates cardiac excitation-contraction coupling (Zheng et al., 2004), $\beta$-AR desensitization (Pippig et al., 1995), I/R tolerance (Sichelschmidt et al., 2003; Peart and Gross, 2006) and cardioprotection via ischemic preconditioning (Sanada et al., 2004; Tong et al., 2005), opioid tolerance (Shen et al., 2000), 


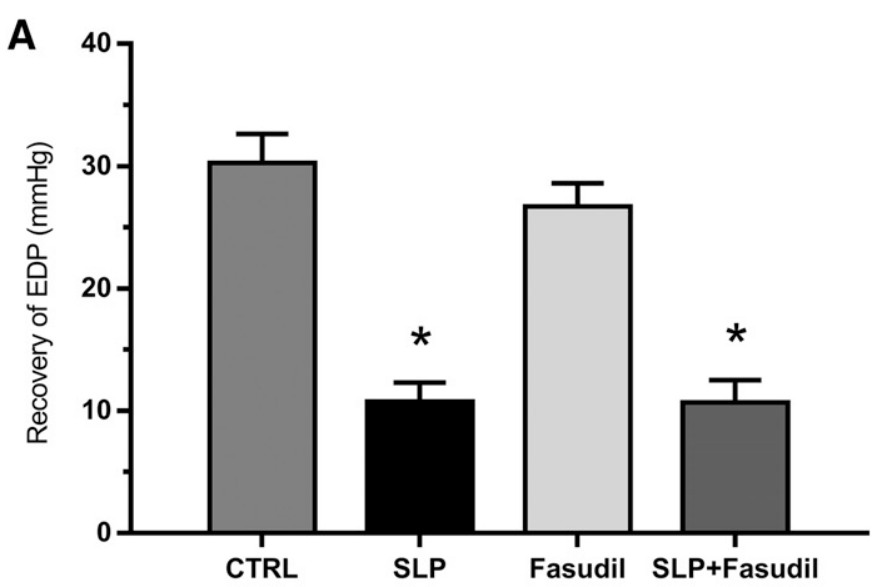

B

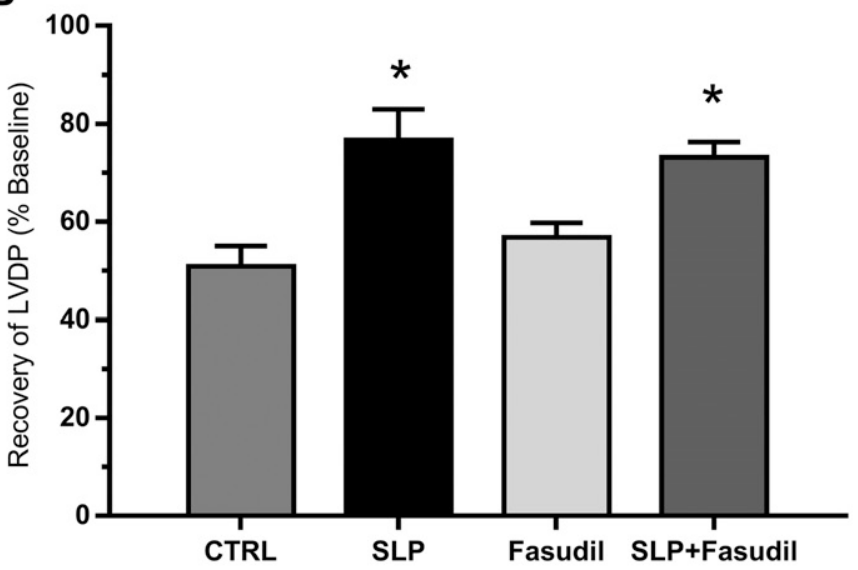

C

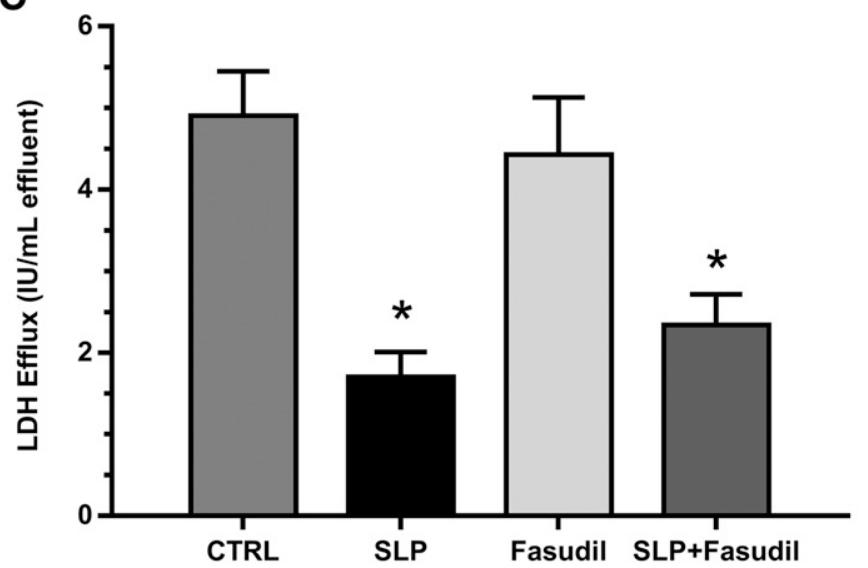

Fig. 4. Effects of ROCK inhibition on ischemic tolerance in control and SLP-treated hearts. Data shown are postischemic recovery of end-diastolic pressure (EDP) (A), recovery of left ventricular developed pressure (LVDP) (B), and cell death (C). Values are mean \pm S.E.; $* P \leq 0.05$ vs. control; $n=6-12$ per group.

and energy metabolism (Maslov et al., 1996). Increased membrane versus decreased cytosolic levels of phospho-PKA arose after 5 days of SLP induction, while there was an early (24 hours) opposing shift in PKA P/T ratios (Table 3). Increased membrane levels of phosphorylated PKA may reflect improved receptor-dependent PKA activation, an effect that may in turn improve $\mathrm{Ca}^{2+}$ homeostasis to reduce I/R injury (Bagchi et al., 1997; Talukder et al., 2007; Yellon and Hausenloy, 2007; Garcia-Dorado et al., 2012). The role of PKA in cardioprotection remains controversial, although PKA can contribute to protection via heat shock protein 20 (Edwards et al., 2012) and ROCK (Sanada et al., 2004). The latter is a serine/threonine protein kinase activated by RhoA GTPase in response to GPCR stimulation (Hamid et al., 2007; Surma et al., 2011). These proteins are associated with $I / R$ injury (Bao et al., 2004; Hamid et al., 2007), cardiomyocyte apoptosis, and other cardiac pathologies (Shi et al., 2011; Surma et al., 2011), although cardiac overexpression of RhoA (upstream of ROCK) improves $I / R$ tolerance in both in vivo and ex vivo models, and RhoA knockout worsens outcomes (Xiang et al., 2011). Conversely, some studies show PKA induces protection via ROCK inhibition to enhance cytoskeletal stability (Sanada et al., 2004). Hamid et al. (2007) demonstrated that ROCK inhibition in rats (5 $\mu \mathrm{M}$ fasudil) reduced myocardial infarct size via an Akt/endothelial nitric oxide synthase-dependent pathway. Here, we demonstrate that ROCK inhibition did not influence intrinsic I/R tolerance or protective SLP effects (Fig. 4). Absence of an effect in the current mouse model versus changes in rats studied by Hamid et al. (2007) suggests species specificity and/or differing roles of ROCK in ex vivo globally ischemic versus in situ regionally ischemic hearts. Failure to modify protection is unlikely to reflect a supra-maximal stimulus with SLP, since additive protection is observed with adenosinergic stimuli, $\mathrm{A}_{1}$ receptors, and caveolin-3 overexpression (Peart et al., 2011; See Hoe et al., 2014).

SLP Does Not Modify Functional Responsiveness to $\boldsymbol{\beta}_{2}$-ARs and AC. Significant elevations in $\beta_{2}$-AR, $\mathrm{G} \alpha$, and PKA expression during SLP induction do not modify baseline cardiac function or functional responses to different $\beta_{2}$-AR agonists or an AC activator (Table 5). Thus, OR-dependent upregulation of the $\beta_{2}$-AR signal axis appears selective for cardioprotective outcomes (Peart and Gross, 2006). It is well documented that cAMP is a promiscuous signaling messenger whose actions are spatially controlled (Zaccolo, 2009). Moreover, the heterogenous landscape of individual GPCR binding sites permits unique GPCR profiles and selective engagement of divergent signaling via single receptors (Valant et al., 2014; Wisler et al., 2014). For example, Headrick et al. (2003) reported opposing effects of age on chronotropic versus cardioprotective responses to adenosine $A_{1}$ receptors, and Valant et al. (2014) showed that a novel $\mathrm{A}_{1}$ receptor ligand selectively protects against $\mathrm{I} / \mathrm{R}$ injury without inducing bradycardia. Lack of functional effects of upregulated $\beta_{2}$-ARs, $\mathrm{G} \alpha_{\mathrm{s}}$, and PKA phosphorylation in the face of emergent $\beta_{2}$-AR- and PKAdependent cardioprotection (Peart and Gross, 2006) indicates selectivity for cardioprotective signaling. Moreover, our prior observation that PKA (or $\beta_{2}$-AR) inhibition eliminates protection during I/R but not during SLP induction (Peart et al., 2011) is consistent with select engagement of this upregulated signal axis by local $\beta$-AR agonists during I/R (Schömig et al., 1984).

PI3K Independence of Signaling Remodeling in SLP. Both PI3K and downstream Akt are widely implicated in cardioprotective responses, participating in so-called reperfusion injury salvage kinase pathways to alleviate I/R injury. Multiple mechanisms may be involved; however, PI3K exerts antiapoptotic actions during myocardial $\mathrm{I} / \mathrm{R}$ via an upstream $\beta_{2}-\mathrm{AR} / \mathrm{G}_{\mathrm{i}}$-coupled-dependent pathway (Chesley et al., 2000). We initially reported that induction of SLP protection appeared to be partly PI3K dependent, while subsequent mediation of protection was partly $\beta_{2}-\mathrm{AR} / \mathrm{G}_{\mathrm{s}} / \mathrm{PKA}$ dependent 
(Peart and Gross, 2006; Peart et al., 2011). Here, we show PI3K activity is nonessential for upregulation of $\beta_{2}-\mathrm{ARs}, \mathrm{G} \alpha_{\mathrm{s}}$, and phospho-PKA over the induction period, although interestingly the molecular effects of sustained PI3K inhibition overlap somewhat with those of SLP. This latter result, in turn, is consistent with prior observations that 5 days of wortmannin treatment induces modest protection (outcomes intermediate between untreated and SLP hearts) (Peart et al., 2011). Thus, protein changes documented with wortmannin here may explain cardioprotection previously observed with 5-day wortmannin treatment (Peart et al., 2011). Our prior observations and current data collectively indicate the protected SLP phenotype is induced by both PI3K-dependent and -independent mechanisms, with the latter involving upregulation of a protective $\beta_{2}$-AR/G $\alpha_{\mathrm{s}} / \mathrm{PKA}$ axis mediating acute protection during I/R. This still leaves the basis of PI3Kdependent SLP induction (Peart and Gross, 2006; Peart et al., 2011), and $\beta_{2}-\mathrm{AR} / \mathrm{G} \alpha_{\mathrm{s}} / \mathrm{PKA}$-independent protection (Peart and Gross, 2006; Peart et al., 2011) to be delineated. Interestingly, Akt may participate in PI3K-independent protection. Our data support early PI3K-dependent versus later PI3Kindependent phosphorylation of Akt during SLP induction (Table 4). This latter elevation may contribute to PI3Kindependent protection during I/R (Peart and Gross, 2006; Peart et al., 2011), given evidence of cytoprotection via PKAdependent (and wortmannin-resistant) Akt activation in other cells (Filippa et al., 1999). Wortmannin-insensitive Akt activation in response to $\beta$-AR agonism has also been observed in other tissues (Moule et al., 1997).

Clinical Utility. Cardiac conditioning remains a clinically desirable yet unrealized goal. Novel SLP effectively reduces $\mathrm{I} / \mathrm{R}$ injury in young and senescent hearts, a significant advantage over conventional cardioprotective stimuli (i.e., high sensitivities to age, disease, and chronic pharmacotherapy). While SLP would have limited applicability to acute myocardial infarction (outside of postconditioning), there may be clinical utility with planned/surgical I/R (such as transplant or coronary artery bypass grafting). Nonetheless, the primary goal of this and ongoing SLP studies is to reveal the potentially novel mechanisms that underlie SLP. A mechanistic understanding of SLP will permit the tailoring of acute therapeutic interventions to achieve highly sought after cardioprotection in acute myocardial infarction and planned/surgical I/R.

\section{Summary}

The present study broadens our mechanistic understanding of the SLP phenotype, identifying upregulation of $\beta_{2}$-ARs and $\mathrm{G} \alpha_{\mathrm{S}}$ variants together with PKA phosphorylation potentially inducing cardioprotection during subsequent I/R. Induction of this $\beta_{2}-\mathrm{AR} / \mathrm{G} \alpha_{\mathrm{S}} / \mathrm{PKA}$ signal axis appears largely PI3K dependent (although SLP upregulates wortmannin-insensitive Akt phosphorylation), and protection does not involve ROCK signaling. While we do not determine how this upregulated signal axis is activated during I/R, it may be in response to endogenous catecholamine release, a well-established consequence of ischemia (Schömig et al., 1984; Kurz et al., 1995). It is possible upregulated $\beta_{2}$-ARs also interact with $\delta$ - and $\kappa$-ORs via heterodimerization (Jordan et al., 2001), although the cardiac relevance and existence of such heteromers is unclear. Moreover, cardiac ORs generally counter $\beta$-AR signaling and responses (Pepe et al., 1997), and studies of heteromers in human embryonic kidney cells suggest dimerization with $\delta$-ORs promotes $\beta_{2}$-AR internalization, while dimerization with $\kappa$-ORs negates $\beta_{2}$-AR activation of mitogen-activated protein kinases (Jordan et al., 2001). Further investigation is needed to identify mechanisms by which $\beta_{2}$-AR, $\mathrm{G} \alpha_{\mathrm{s}}$, and PKA are upregulated during sustained OR agonism, how this $\beta_{2}$-AR axis is subsequently activated, and what end effectors are engaged to induce protection. Moreover, the identification of PI3K-dependent induction mechanisms implicated in earlier work (Peart and Gross, 2006; Peart et al., 2011), which may underlie $\beta_{2}$-AR independent cardioprotection with SLP, remains to be identified.

\section{Authorship Contributions}

Participated in research design: See Hoe, Foster, Headrick, Peart. Conducted experiments: See Hoe, Wendt.

Performed data analysis: See Hoe, Wendt, Peart.

Wrote or contributed to the writing of the manuscript: See Hoe, Foster, Wendt, Patel, Headrick, Peart.

\section{References}

Bagchi D, Wetscher GJ, Bagchi M, Hinder PR, Perdikis G, Stohs SJ, Hinder RA, and Das DK (1997) Interrelationship between cellular calcium homeostasis and free radical generation in myocardial reperfusion injury. Chem Biol Interact 104: $65-85$.

Baltensperger K, Karoor V, Paul H, Ruoho A, Czech MP, and Malbon CC (1996) The $\beta$-adrenergic receptor is a substrate for the insulin receptor tyrosine kinase. J Biol Chem 271:1061-1064.

Bao W, Hu E, Tao L, Boyce R, Mirabile R, Thudium DT, Ma XL, Willette RN, and Yue TL (2004) Inhibition of Rho-kinase protects the heart against ischemia/reperfusion injury. Cardiovasc Res 61:548-558.

Bernstein D, Fajardo G, and Zhao M (2011) The role of $\beta$-adrenergic receptors in heart failure: differential regulation of cardiotoxicity and cardioprotection. Prog Pediatr Cardiol 31:35-38.

Budiono BP, See Hoe LE, Brunt AR, Peart JN, Headrick JP, and Haseler LJ (2016) Coupling of myocardial stress resistance and signalling to voluntary activity and inactivity. Acta Physiol (Oxf) 218:112-122.

Chesley A, Lundberg MS, Asai T, Xiao RP, Ohtani S, Lakatta EG, and Crow MT (2000) The $\beta_{2}$-adrenergic receptor delivers an antiapoptotic signal to cardiac myocytes through $\mathrm{G}_{\mathrm{i}}$-dependent coupling to phosphatidylinositol 3'-kinase. Circ Res 87:1172-1179.

Cross HR, Steenbergen C, Lefkowitz RJ, Koch WJ, and Murphy E (1999) Overexpression of the cardiac beta(2)-adrenergic receptor and expression of a betaadrenergic receptor kinase-1 (betaARK1) inhibitor both increase myocardial contractility but have differential effects on susceptibility to ischemic injury. Circ Res 85:1077-1084.

Davis DJ, Hickman JM, Lefebvre CA, and Lyon ME (1992) Insulin inhibits betaadrenergic responses in fetal rabbit lung in explant culture. Am $J$ Physiol $\mathbf{2 6 3}$ : L562-L567.

Dror RO, Arlow DH, Borhani DW, Jensen MO, Piana S, and Shaw DE (2009) Identification of two distinct inactive conformations of the $\beta_{2}$-adrenergic receptor reconciles structural and biochemical observations. Proc Natl Acad Sci USA 106: 4689-4694.

Edwards HV, Scott JD, and Baillie GS (2012) PKA phosphorylation of the small heatshock protein Hsp20 enhances its cardioprotective effects. Biochem Soc Trans 40 $210-214$

Eschenhagen T (1993) G proteins and the heart. Cell Biol Int 17:723-749.

Filippa N, Sable CL, Filloux C, Hemmings B, and Van Obberghen E (1999) Mechanism of protein kinase B activation by cyclic AMP-dependent protein kinase. Mol Cell Biol 19:4989-5000.

Garcia-Dorado D, Ruiz-Meana M, Inserte J, Rodriguez-Sinovas A, and Piper HM (2012) Calcium-mediated cell death during myocardial reperfusion. Cardiovasc Res 94:168-180.

Grimm M and Brown JH (2010) $\beta$-Adrenergic receptor signaling in the heart: role of CaMKII. J Mol Cell Cardiol 48:322-330.

Gross ER, Hsu AK, and Gross GJ (2004) Opioid-induced cardioprotection occurs via glycogen synthase kinase beta inhibition during reperfusion in intact rat hearts. Circ Res 94:960-966.

Gross ER, Peart JN, Hsu AK, Auchampach JA, and Gross GJ (2005) Extending the cardioprotective window using a novel $\delta$-opioid agonist fentanyl isothiocyanate via the PI3-kinase pathway. Am J Physiol Heart Circ Physiol 288: $\mathrm{H} 2744-\mathrm{H} 2749$.

Guo H, Zheng H, Wu J, Ma HP, Yu J, and Yiliyaer M (2017) The key role of microtubules in hypoxia preconditioning-induced nuclear translocation of HIF- $1 \alpha$ in rat cardiomyocytes. PeerJ 5:e3662.

Hadcock JR, Port JD, Gelman MS, and Malbon CC (1992) Cross-talk between tyrosine kinase and G-protein-linked receptors. Phosphorylation of $\beta_{2}$-adrenergic receptors in response to insulin. J Biol Chem 267:26017-26022.

Hamid SA, Bower HS, and Baxter GF (2007) Rho kinase activation plays a major role as a mediator of irreversible injury in reperfused myocardium. Am J Physiol Heart Circ Physiol 292:H2598-H2606. 
Headrick JP, See Hoe LE, Du Toit EF, and Peart JN (2015) Opioid receptors and cardioprotection-'opioidergic conditioning' of the heart. $\mathrm{Br} J$ Pharmacol 172: $2026-2050$

Headrick JP, Willems L, Ashton KJ, Holmgren K, Peart J, and Matherne GP (2003) Ischaemic tolerance in aged mouse myocardium: the role of adenosine and effects of $\mathrm{A}_{1}$ adenosine receptor overexpression. $J$ Physiol 549:823-833.

Hebert TE, Loisel TP, Adam L, Ethier N, Onge SS, and Bouvier M (1998) Functional rescue of a constitutively desensitized beta2AR through receptor dimerization. Biochem J 330:287-293.

Hickman J and McElduff A (1990) Insulin sensitizes a cultured rat osteogenic sarcoma cell line to hormones which activate adenylate cyclase. Calcif Tissue Int 46: 401-405.

Johnson MD, Zhou Y, Friedman E, and Roberts J (1995) Expression of G protein $\alpha$ subunits in the aging cardiovascular system. J Gerontol A Biol Sci Med Sci 50A B14-B19.

Jordan BA, Trapaidze N, Gomes I, Nivarthi R, and Devi LA (2001) Oligomerization of opioid receptors with $\beta_{2}$-adrenergic receptors: a role in trafficking and mitogenactivated protein kinase activation. Proc Natl Acad Sci USA 98:343-348.

Kurz T, Richardt G, Hagl S, Seyfarth M, and Schömig A (1995) Two different mechanisms of noradrenaline release during normoxia and simulated ischemia in human cardiac tissue. J Mol Cell Cardiol 27:1161-1172.

Lochner A, Genade S, Tromp E, Podzuweit T, and Moolman JA (1999) Ischemic preconditioning and the $\beta$-adrenergic signal transduction pathway. Circulation 100:958-966

Lohse MJ, Andexinger S, Pitcher J, Trukawinski S, Codina J, Faure JP, Caron MG, and Lefkowitz RJ (1992) Receptor-specific desensitization with purified proteins. Kinase dependence and receptor specificity of $\beta$-arrestin and arrestin in the $\beta_{2^{-}}$ adrenergic receptor and rhodopsin systems. J Biol Chem 267:8558-8564.

Ma L and Pei G (2007) $\beta$-Arrestin signaling and regulation of transcription. J Cell Sci 120:213-218.

Marmor M, Penn A, Widmer K, Levin RI, and Maslansky R (2004) Coronary artery disease and opioid use. Am J Cardiol 93:1295-1297.

Maslov LN, Krylatov AV, and Lishmanov IuB (1996) Participation of endogenous muand delta-opiate receptor agonists in mechanisms of the anti-arrhythmia effect of adaptation. Biull Eksp Biol Med 121:24-25.

Miyamoto A, Kawana S, Kimura H, and Ohshika H (1994) Impaired expression of $\mathrm{G}_{\mathrm{s} \alpha}$ protein mRNA in rat ventricular myocardium with aging. Eur $J$ Pharmacol 266:147-154

Moule SK, Welsh GI, Edgell NJ, Foulstone EJ, Proud CG, and Denton RM (1997) Regulation of protein kinase B and glycogen synthase kinase-3 by insulin and $\beta$-adrenergic agonists in rat epididymal fat cells. Activation of protein kinase B by wortmannin-sensitive and -insensitive mechanisms. J Biol Chem 272:7713-7719.

Napier LD, Roerig SC, Yoshishige DA, Barron BA, and Caffrey JL (1999) Canine cardiac muscarinic receptors, $\mathrm{G}$ proteins, and adenylate cyclase after long-term morphine. J Pharmacol Exp Ther 291:725-732.

Novotny J, Bourová L, Kolár F, and Svoboda P (2001) Membrane-bound and cytosolic forms of heterotrimeric $\mathrm{G}$ proteins in young and adult rat myocardium: influence of neonatal hypo- and hyperthyroidism. $J$ Cell Biochem 82:215-224.

Novotny J, Bourová L, Málková O, Svoboda P, and Kolár F (1999) G proteins, $\beta$-adrenoreceptors and $\beta$-adrenergic responsiveness in immature and adult rat ventricular myocardium: influence of neonatal hypo- and hyperthyroidism. $J \mathrm{Mol}$ Cell Cardiol 31:761-772.

Novotny J and Svoboda P (1998) The long (Gs(alpha)-L) and short (Gs(alpha)-S) variants of the stimulatory guanine nucleotide-binding protein. Do they behave in an identical way? J Mol Endocrinol 20:163-173

Olianas MC, Dedoni S, and Onali P (2011) $\delta$-Opioid receptors stimulate GLUT1mediated glucose uptake through Src- and IGF-1 receptor-dependent activation of PI3-kinase signalling in CHO cells. Br J Pharmacol 163:624-637.

Peart JN, Gross ER, Headrick JP, and Gross GJ (2007) Impaired p38 MAPK/HSP27 signaling underlies aging-related failure in opioid-mediated cardioprotection. $J$ Mol Cell Cardiol 42:972-980.

Peart JN and Gross GJ (2003) Adenosine and opioid receptor-mediated cardioprotection in the rat: evidence for cross-talk between receptors. Am J Physiol Heart Circ Physiol 285:H81-H89.

Peart JN and Gross GJ (2004a) Chronic exposure to morphine produces a marked cardioprotective phenotype in aged mouse hearts. Exp Gerontol 39:1021-1026

Peart JN and Gross GJ (2004b) Morphine-tolerant mice exhibit a profound and persistent cardioprotective phenotype. Circulation 109:1219-1222.

Peart JN and Gross GJ (2006) Cardioprotective effects of acute and chronic opioid treatment are mediated via different signaling pathways. Am J Physiol Heart Circ Physiol 291:H1746-H1753.

Peart JN and Headrick JP (2009) Clinical cardioprotection and the value of conditioning responses. Am J Physiol Heart Circ Physiol 296:H1705-H1720.

Peart JN, Hoe LE, Gross GJ, and Headrick JP (2011) Sustained ligand-activated preconditioning via $\delta$-opioid receptors. $J$ Pharmacol Exp Ther 336:274-281.

Peart JN, Pepe S, Reichelt ME, Beckett N, See Hoe L, Ozberk V, Niesman IR, Patel HH, and Headrick JP (2014) Dysfunctional survival-signaling and stressintolerance in aged murine and human myocardium. Exp Gerontol 50:72-81.

Pepe S, Xiao RP, Hohl C, Altschuld R, and Lakatta EG (1997) 'Cross talk' between opioid peptide and adrenergic receptor signaling in isolated rat heart. Circulation 95:2122-2129.

Pippig S, Andexinger S, and Lohse MJ (1995) Sequestration and recycling of beta 2-adrenergic receptors permit receptor resensitization. Mol Pharmacol 47: 666-676.

Reichelt ME, Willems L, Hack BA, Peart JN, and Headrick JP (2009) Cardiac and coronary function in the Langendorff-perfused mouse heart model. Exp Physiol 94: $54-70$
Sager G, Johansen O, and Mjøs OD (1990) Effects of insulin on mononuclear leukocyte $\beta$-adrenoceptor density and adenylate cyclase coupling. Eur J Pharmacol 188:243-249. Salie R, Moolman JA, and Lochner A (2011) The role of $\beta$-adrenergic receptors in the cardioprotective effects of beta-preconditioning $(\beta \mathrm{PC})$. Cardiovas Drugs Ther $\mathbf{2 5}$ $31-46$.

Salie R, Moolman JA, and Lochner A (2012) The mechanism of beta-adrenergic preconditioning: roles for adenosine and ROS during triggering and mediation. Basic Res Cardiol 107:281.

Sanada S, Asanuma H, Tsukamoto O, Minamino T, Node K, Takashima S, Fukushima T, Ogai A, Shinozaki Y, Fujita M, et al. (2004) Protein kinase A as another mediator of ischemic preconditioning independent of protein kinase $\mathrm{C}$. Circulation 110:51-57.

Schömig A, Dart AM, Dietz R, Mayer E, and Kübler W (1984) Release of endogenous catecholamines in the ischemic myocardium of the rat. Part A: locally mediated release. Circ Res 55:689-701.

See Hoe LE, Schilling JM, Busija AR, Haushalter KJ, Ozberk V, Keshwani MM, Roth DM, Toit ED, Headrick JP, Patel HH, et al. (2016) Chronic $\beta_{1}$-adrenoceptor blockade impairs ischaemic tolerance and preconditioning in murine myocardium. Eur J Pharmacol 789:1-7.

See Hoe LE, Schilling JM, Tarbit E, Kiessling CJ, Busija AR, Niesman IR, Du Toit E, Ashton KJ, Roth DM, Headrick JP, et al. (2014) Sarcolemmal cholesterol and caveolin-3 dependence of cardiac function, ischemic tolerance, and opioidergic cardioprotection. Am J Physiol Heart Circ Physiol 307:H895-H903.

Shen J, Benedict Gomes A, Gallagher A, Stafford K, and Yoburn BC (2000) Role of cAMP-dependent protein kinase (PKA) in opioid agonist-induced $\mu$-opioid receptor downregulation and tolerance in mice. Synapse 38:322-327.

Shi J, Zhang L, and Wei L (2011) Rho-kinase in development and heart failure: insights from genetic models. Pediatr Cardiol 32:297-304.

Shu Y and Scarpace PJ (1994) Forskolin binding sites and G-protein immunoreactivity in rat hearts during aging. $J$ Cardiovasc Pharmacol 23:188-193.

Sichelschmidt OJ, Hahnefeld C, Hohlfeld T, Herberg FW, and Schrör K (2003) Trapidil protects ischemic hearts from reperfusion injury by stimulating PKAII activity. Cardiovasc Res 58:602-610.

Surma M, Wei L, and Shi J (2011) Rho kinase as a therapeutic target in cardiovascular disease. Future Cardiol 7:657-671.

Sutherland FJ, Baker KE, Shattock MJ, and Hearse DJ (2003) Responses to ischaemia and reperfusion in the mouse isolated perfused heart and the phenomenon of 'contractile cycling'. Clin Exp Pharmacol Physiol 30:879-884.

Talukder MA, Kalyanasundaram A, Zhao X, Zuo L, Bhupathy P, Babu GJ, Cardoune AJ, Periasamy M, and Zweier JL (2007) Expression of SERCA isoform with faster $\mathrm{Ca}^{2+}$ transport properties improves postischemic cardiac function and $\mathrm{Ca}^{2+}$ handling and decreases myocardial infarction. Am J Physiol Heart Circ Physiol 293: $\mathrm{H} 2418-\mathrm{H} 2428$.

Tong H, Bernstein D, Murphy E, and Steenbergen C (2005) The role of $\beta$-adrenergic receptor signaling in cardioprotection. FASEB J 19:983-985.

Urasawa K, Murakami T, and Yasuda H (1991) Age-related alterations in adenylyl cyclase system of rat hearts. Jpn Circ $J$ 55:676-684.

Valant C, May LT, Aurelio L, Chuo CH, White PJ, Baltos JA, Sexton PM, Scammells PJ, and Christopoulos A (2014) Separation of on-target efficacy from adverse effects through rational design of a bitopic adenosine receptor agonist. Proc Natl Acad Sci USA 111:4614-4619.

Valiquette M, Parent S, Loisel TP, and Bouvier M (1995) Mutation of tyrosine-141 inhibits insulin-promoted tyrosine phosphorylation and increased responsiveness of the human beta 2-adrenergic receptor. EMBO J 14:5542-5549.

van Tits LJ, Daul A, Bauch HJ, Grosse-Wilde H, Happel M, Michel MC, and Brodde OE (1990) Effects of insulin-induced hypoglycemia on beta 2-adrenoceptor density and proliferative responses of human lymphocytes. J Clin Endocrinol Metab 71: 187-192.

Williams-Pritchard G, Knight M, Hoe LS, Headrick JP, and Peart JN (2011) Essential role of EGFR in cardioprotection and signaling responses to $\mathrm{A}_{1}$ adenosine receptors and ischemic preconditioning. Am J Physiol Heart Circ Physiol 300: H2161-H2168.

Wisler JW, Xiao K, Thomsen AR, and Lefkowitz RJ (2014) Recent developments in biased agonism. Curr Opin Cell Biol 27:18-24.

Xiang SY, Vanhoutte D, Del Re DP, Purcell NH, Ling H, Banerjee I, Bossuyt J, Lang RA, Zheng Y, Matkovich SJ, et al. (2011) RhoA protects the mouse heart against ischemia/reperfusion injury. J Clin Invest 121:3269-3276.

Xiang YK (2011) Compartmentalization of beta-adrenergic signals in cardiomyocytes. Circ Res 109:231-244.

Yagami T (1995) Differential coupling of glucagon and beta-adrenergic receptors with the small and large forms of the stimulatory G protein. Mol Pharmacol 48:849-854.

Yellon DM and Hausenloy DJ (2007) Myocardial reperfusion injury. $N$ Engl J Med 357:1121-1135.

Yu JZ, Dave RH, Allen JA, Sarma T, and Rasenick MM (2009) Cytosolic G $\alpha_{\mathrm{s}}$ acts as an intracellular messenger to increase microtubule dynamics and promote neurite outgrowth. J Biol Chem 284:10462-10472.

Zaccolo M (2009) cAMP signal transduction in the heart: understanding spatial control for the development of novel therapeutic strategies. Br J Pharmacol 158:50-60.

Zheng M, Han QD, and Xiao RP (2004) Distinct $\beta$-adrenergic receptor subtype signaling in the heart and their pathophysiological relevance. Sheng Li Xue Bao 56:1-15.

Address correspondence to: Dr. L. E. See Hoe, Prince Charles Hospital, Clinical Sciences Building, Room 13, Level 3, Chermside, QLD 4032 Australia; Critical Care Research Group, Faculty of Medicine, University of Queensland, Brisbane, Australia. E-mail: l.seehoe@uq.edu.au 